\title{
RAISING AWARENESS OF SCHOOL SOCIAL WORK IN SLOVAKIA Veronika Šimonová ${ }^{1}$, Miroslav Tvrdoñ $^{2}$
}

\begin{abstract}
The objective of the present study was to point out the current perception of the roles of school social workers and other professional staff members in secondary schools from the perspective of school managers. In conducting the research, the authors focused on interrelationships between social work and education. In using the qualitative method of semi-structured interviews, the authors analysed the current state in the school environment from the perspective of school managers in secondary schools in the Nitra Region. There were 16 respondents included in the study. According to the respondents, the school environment is able to recruit professional staff members, and thus reflect the increasing need for professional interventions in dealing with increasing social risk factors. According to our findings, the most acceptable form is employing a school social worker directly by the school. In the present, however, there is insufficient funding, legislative anchoring of school social work, and specialised education for social workers.
\end{abstract}

UDC Classification: 364.4, DOI: 10.12955/cbup.v7.1430

Keywords: secondary school, student, school social work.

\section{Introduction}

One of the key factors in the process of professionalization of school social work abroad is research in the field. It has contributed essentially to the implementation of school social work in many countries where school social workers are an indispensable part of educational institutions. Social work as a social institution reflected the current challenges and demands of the time in which it evolved. The need for school social work was already present since the beginning of the previous century and has not changed for more than a century. Only the objectives and interventions based on the political and societal contexts, as well as research findings, have been changing (Skyba, 2015). Despite many obstacles, it retains an indispensable position and is generally accepted in the society.

In Slovakia in 1999, Labáth stated the legitimacy of the social worker in the school environment, as he considered the social worker to be an expert on the social environment. "He understands the mechanisms of the impact of the social environment on an individual, knows the dynamism of small and large social groups and organisations, knows the risks and potential of social relations, and has knowledge on the aetiology of children and young people at risk, especially on the negative social factors. He can reliably assess the effects of a given social environment on an individual. The social worker has methods of influencing the environment by social mechanisms - for example by developing a positive peer culture, stimulating open two-way communication, developing the community principles, collaborating with families and social networks. All this can be achieved through group work, intertwining the out-ofschool environment and school system, out-of-school activities, and working with school as a social system" (Labáth, 1999, p. 3; translated by the study authors).

Only in 2006 we can talk about the beginning of school social work in Slovak schools. That year, through the project School Social Work implemented by the town of Považská Bystrica, there was one school social worker in two primary schools. Furthermore, there was a social worker at the grammar school in Trnava. Later, for a short period of time, there were school social workers in schools in Nová Dubnica, Ilava and Svinná (Vasil’ová and Lovašová, 2018).

However, those posts were abolished. According to Lengyel (2016), one of the main causes was the legislative amendment of the School Act in 2008 by which the post of social pedagogue was included in the professional staff. School social workers were not included in the legislative amendment despite the initiative by the professional public. In the present, there are no school social workers in schools in Slovakia.

One of the conditions for the successful implementation of school social work in Slovakia is the readiness of the educational system and society to reflect the changing needs of children and young people, and to respond to these changes. Such readiness was one of the central aspects present during the formation and successful implementation of school social work abroad (Skyba, 2015).

At present, social workers are perceived internationally as trained professionals who provide services related to personal, social and emotional coping with life challenges of an individual - pupil in school

\footnotetext{
${ }^{1}$ Constantine the Philosopher University in Nitra, Slovakia, veronka.simonova@gmail.com

${ }^{2}$ Constantine the Philosopher University in Nitra, Slovakia, mtvrdon2@ukf.sk
} 
and society. They connect the home environment, the school environment and the community. They support pupils and their successful management of stress situations affecting the learning process. School social work is perceived as a specialised area of social work practice which can be performed after successful completion of further education. In the school environment, competent social workers are able to provide unique knowledge and skills. Their services can be divided into five levels:

- Services provided to students

- Services provided to parents and families

- Services provided to pedagogical and professional staff

- Services provided to the community

- Services to the general public

- Administrative and coordination activities (SSWAA, 2018).

\section{Data and methodology}

We have formulated the research problem as follows: What are the opportunities for school social work in Slovakia? For the purposes of the paper, we draw attention to the results of our research which show the acute need for changes in the school environment, the negative effects of the absence of professional staff in schools, and also the obstacles on the basis of which school managers cannot employ professional staff.

The sample consisted of the school managers at secondary schools, i.e. the head teachers and deputy head teachers at the secondary schools in the Nitra Region. We limited the research on a territorial basis related to the size of the sample. In the Nitra Region, there are currently 87 secondary schools whose founder is the Nitra Self-Governing Region and nine church secondary schools (SSaSZ, 2018). We decided for these respondents because the head teachers and deputy head teachers conduct and are present at interviews with pupils and their parents. The key inclusion criterion was the fact that it is them that are competent to get social workers and other professional staff into the school environment. Based on our research results, we argue that the future implementation of school social work in our conditions depends on their belief and initiative. There were managers of 16 secondary vocational schools, ten deputy head teachers and six head teachers, participating in the study.

There were $25 \%$ of all secondary vocational schools in the Nitra Region participating, i.e. $16.67 \%$ of secondary schools from the total number of secondary schools in the Nitra Self-Governing Region.

We used a qualitative research design and collected the data with the use of semi-structured interviews in 2017 and 2018. We analysed the data by open coding.

\section{Results}

In the following tables, we list the most important results.

According to the respondents it was important that the government provides schools with real possibilities to employ a professional staff member. His importance and benefits for schools are evident to them, but in seven schools where they did not have any professional staff members, they will not be able to employ professional staff members even in the near future. They do not have the financial and material possibilities, even if they see a constantly increasing need for their presence.

The importance of the presence of a professional staff member in schools was confirmed by the fact that all respondents cooperate with external organisations (e.g. pedagogical and psychological counselling and prevention centres, or specialised pedagogical counselling centres) only in extreme situations when they are not able to tackle the situation on their own. In cases which must be reported, they cooperate only with the police. In addition, intermittently they use some of the offers they get, including one-time workshops, concerts, or professional lectures. As the respondents stated, they lack the confidence that the intervention might actually help the pupil and, in many cases, they think that it would be correct to proceed in a different way than suggested by the expert, but they have no impact on the change. If such an expert is right in the school, and is an employee of the school, the respondents have an opportunity to express their opinions, intervene in the process, or discuss the correctness of a chosen strategy, or see what the reaction of the pupil or his family to the expert's intervention is, and see the results in the long term. 


\begin{tabular}{|l|c|}
\hline \multicolumn{2}{|l|}{ Table 1: Necessary changes in the educational system from the respondents' perspective } \\
\hline Necessary changes in the educational system from the respondents' perspective & $\mathrm{N}=$ \\
\hline Abolition of funding by the number of pupils & 16 \\
\hline Centralisation of the secondary educational system directly under the Ministry of Education & 7 \\
\hline Assigning the secondary schools to individual municipalities & 2 \\
\hline Involvement of school managers in drafting legislative proposals & 12 \\
\hline Cancelling Year 9 at primary schools & 8 \\
\hline Obligation for all schools to employ a professional staff member & 14 \\
\hline Reduce the number of schools & 16 \\
\hline Reconsidering the priorities in education & 6 \\
\hline Source: Author & \\
\hline
\end{tabular}

\begin{tabular}{|l|c|c|}
\hline \multicolumn{2}{|l|}{ Table 2: Negatives of employing a professional staff member } & Categories \\
\hline Codes & $\mathrm{N}=$ \\
\hline $\begin{array}{l}\text { Reduction of teacher's work load at the expense of the salary for a } \\
\text { professional staff member; decision making whether to employ a } \\
\text { necessary teacher or professional staff member; }\end{array}$ & $\begin{array}{c}\text { Draining the school } \\
\text { budget }\end{array}$ & 9 \\
\hline $\begin{array}{l}\text { Non-acceptance and disbelief by teachers; perplexed responses by } \\
\text { teachers; requiring delicate information about pupils; expectations that } \\
\text { professional staff members will agree with teachers on everything; } \\
\text { failure to respect the advice and recommendations provided by a } \\
\text { professional staff member; }\end{array}$ & $\begin{array}{c}\text { Rejecting attitudes } \\
\text { among teachers }\end{array}$ & 7 \\
\hline $\begin{array}{l}\text { Persistent social risk factors; the results of work came up gradually, in } \\
\text { some cases after a longer period of time; pupils needed more time to get } \\
\text { used to a fact that there was a professional staff member in their school } \\
\text { and before it occurred to them that they could visit him with their } \\
\text { problems; a large number of pupils still address their teachers or school } \\
\text { managers with the problems that are the responsibility of a professional } \\
\text { staff member; }\end{array}$ & $\begin{array}{c}\text { Absence of immediate } \\
\text { results }\end{array}$ & 6 \\
\hline Source: Author & \\
\hline
\end{tabular}

\begin{tabular}{|l|c|c|}
\hline \multicolumn{3}{|l|}{ Table 3: Negative consequences of absence of a professional staff member in schools } \\
\hline $\begin{array}{l}\text { Codes } \\
\begin{array}{l}\text { Exhaustion of the respondents, teachers; working beyond the paid } \\
\text { working time; transfer of problems to the home environment; enormous } \\
\text { workload of the staff; the emphasis on teachers' education, not only for } \\
\text { the purposes of enhancing their skills, but also for the purposes of } \\
\text { providing quality interventions in dealing with social risk factors; } \\
\text { directives, prevention materials addressed mainly to teachers }\end{array}\end{array}$ & Employee burnout & 12 \\
\hline $\begin{array}{l}\text { Non-professional interventions by the respondents, teachers; } \\
\text { identification with the pupil's parent's role; acting outside their } \\
\text { competence; failure to fulfil obligations in reporting social risk factors; } \\
\text { lacking professional diagnosis of social risk factors; self-help problem } \\
\text { solution; lacking cooperation with external institutions; the problems are } \\
\text { only spoken about but there is no action; lacking preparedness of staff } \\
\text { for a wide range of social risk factors occurring in the school } \\
\text { environment }\end{array}$ & $\begin{array}{c}\text { Non-professional } \\
\text { procedures in tackling } \\
\text { social risk factors }\end{array}$ & 10 \\
\hline Source: Author & & \\
\hline
\end{tabular}

\section{Discussion}

In our research, we focused on finding the respondents' opinions on the roles of social workers in schools. According to the respondents, they would like a social worker to be in the post of prevention and educational counsellor. If possible, they would exempt a teacher from this post which includes not only other responsibilities, trainings, administration, but it also requires greater skills and abilities, for 
example crisis management, working with pupils not just as a teacher, which, in the words of the respondents, causes considerable difficulties to the staff. Three respondents were satisfied with the performance of the prevention coordinator and the educational counsellor in their school. Four respondents out of 13 stated that they explicitly cover his activity, and in most cases, they or other colleagues from the school management deal with situations that belong to his agenda. Six respondents stated that they were not satisfied with preventive activities or their forms. In addition to the notice boards on the subject, one-time educational concerts, theatre performances and one-time lectures by selected guests, there are no other prevention activities performed with pupils. Three respondents stated that what is legally defined in these posts, it is also fulfilled, but they know from the teachers themselves that these functions are carried out only on the grounds that they have the sufficient number of hours of work or at least a slightly higher salary. A particular relationship to this activity or belief about the importance and relevance of this activity were absent. Therefore, the respondents would welcome if these activities would not have to be carried out by a pedagogical staff member, convinced that this could automatically enhance their level and effect. According to the respondents, other activities that could be included in the work of social workers were working with families, working with a class, in particular for the purposes of adapting pupils coming from a primary school to a secondary school, or training of communication and social skills in pupils. They also saw a small space in the lessons of selected subjects and thematic units, or cross-sectional themes. In their opinion, the social worker could lead these lessons and carry out ready-made activities. Six respondents at whose school there was a school psychologist stated that if they had a social worker at their school too, he might perform some activities done by a psychologist, such as group prevention activities, and participation in various school events and trips. As they stated, if the government created the conditions for employing a social worker, they would not refuse it. At this point, we also outlined the post of social pedagogue which may be carried out by a social worker. None of the schools employed or planned to employ a social pedagogue and did not know anything about his possible activities in the school environment. Even though they knew that this post was legislatively anchored, it was surprising for them that we considered these two experts, a social pedagogue and a school social worker, equal. We did so on the basis of a literature review. Klein and Rosinský (2013) state that "the priority of a social pedagogue (school social worker) is to create a healthy social system in schools that accepts the individuality of the pupil, stimulates his potential, promotes positive emotions, does not cause fear, mediates the experience of success, teaches to communicate openly, prefers cooperation, etc." (Klein, Rosinský, 2013, p. 99; translated by the authors).

A social pedagogue at school can fulfil a cumulated function of both a social pedagogue and a prevention coordinator. The post of social pedagogue as a professional staff member is not yet sufficiently occupied in schools, despite an increase in the incidence of socio-pathological phenomena. The post of prevention coordinator is often performed by a pedagogue teaching two subjects merely formally because of his workload in the educational process (Klein, Rosinský, 2013, p. 105).

Similar activities to those included by our respondents in the job description of school social workers were also stated by teachers participating in the study by Skyba (2015). The respondents in the study expected from a school social worker an assessment of the pupil's family environment, consulting at all levels, and communication and close cooperation with social welfare authorities, other organisations and in particular the pupil's family. According to them, the main target groups of school social workers should be in particular pupils with emotional problems and behavioural disorders, and pupils who have problems with their inclusion, school attendance, and problems with addictions or aggressive behaviour.

Roles of social workers in the school environment:

A school social worker as a staff member - the benefits of employing a social worker directly by a school can include a detailed overview of the functioning of the school and its internal system, hierarchy, climate, educational goals and active participation in school life. The teaching staff are sufficiently familiar with his work and there is faster acceptance of his action, as he is present in the school environment to the same extent as other pedagogical staff. This way of employment creates a space to get to know not only the pupils and classroom environment, but also to get to know individual teachers and develop workplace relations, mutual respect and effective cooperation. The social worker can respond promptly to the situation and it is not necessary to wait for his arrival and intervention, or to provide him with important information again and again. An advantage is also his own space, office, 
technical and material equipment being constantly available. The social worker has adequate space to create a stable multidisciplinary team and reconcile his work with teachers as well as other professional staff members and define individual competences and tasks. At the same time, within his profession, he does not have to travel so often. Of course, such a relation also brings disadvantages as a direct subordination to the school management, accountability for all his activities to the school management, less control over the use of his working time, and also less space to meet other extra-curricular activities. There is a risk of a reduced rate of objectivity and complying with the school's efforts to achieve its best possible image. Another threat is in the greater isolation from the community and in the possible absorption by the school's internal problems. Furthermore, also from the outer perspective they are primarily perceived as school staff members and can be perceived as part of systemic problems of the educational system. Therefore, it is necessary for a social worker to have the necessary personality characteristics and professional capabilities to identify and respond to the threats (Link, 1991).

A school social worker as an employee of a self-governing region, a municipality, an office of labour, social affairs and family, or as a self-employed person - based on the examples of the implementation of a school social worker in Austria, we state the possibility of funding school social workers through projects subsidized by the national or European funds. One of such forms of funding is the non-repayable financial contribution for projects in various operational programmes, such as the Operational Programme Human Resources, funded by the European Social Fund and the European Regional Development Fund. In case of the project implementation through which a social worker could operate at school, it would be possible to measure the results of his work and the effects of his action in the school environment for this period, which could contribute to the development of this practice and to a greater interest of schools in the interventions of social workers in their schools.

A school social worker/social worker as a staff member of a counselling facility - the essential parts of this system of educational counselling and prevention are, according to the Act No. 245/2008 (School $\mathrm{Law}$ ), the centres of pedagogical and psychological counselling and prevention (CPPCaP) and specialised pedagogic counselling centres (SPCC). The specialised pedagogic counselling centres can employ special pedagogues, speech therapists, therapeutic pedagogues, psychologists, social workers, physicians, nurses, physiotherapists, or rehabilitation workers. The activities of the social worker as an employee of the centre for the specialised pedagogical intervention focus on coordination activities in the provision of services in the facility, and creating favourable conditions for a successful adaptation to the services provided. The social worker ensures smooth communication between the parties and smooth provision of the services. He is also responsible for recording the information about the clients of a facility and keeping a written agenda on the services provided and the clients. In addition to coordination and administrative activities, he can provide social counselling, and specialised counselling for children with handicaps and their families (CSPP, 2018).

In the Nitra Region, there are 11 state specialised pedagogic counselling centres and 11 private specialised pedagogic counselling centres. There are also eight state centres of pedagogical and psychological counselling and prevention (VÚDPaP, 2018).

There is a social worker currently working in one private specialised pedagogic counselling centre in Nitra and in one state specialised pedagogic counselling centre in Šahy. There are four administrative and social workers working in the centres of pedagogical and psychological counselling who are responsible for administration in the facility, and in two cases they are responsible for the first contact with the client and his family. These facilities are in Nitra, Nové Zámky, Šal'a and Levice. The staff of these facilities include mostly psychologists and special pedagogues, who are employed in all the facilities; in ten facilities (CPCC) there are also speech therapists; in four CPPCaPs and two CPCCs there are also social pedagogues; and in two CPPCaPs there are also therapeutic pedagogues.

The model of a school social worker employed by a municipality or an external institution was supported also by Zeitlin et al. (2005) who, on the basis of their long-term study, found out that a greater success rate and a higher level of work were in school social workers who were not school employees. The essence of this result was that those workers attached much greater importance to their further training.

Molíková (2013) suggests that it might not be necessary for a school social worker to be an employee of the school, provided that an educational counsellor, or a school psychologist or other expert would be able to cooperate actively and have a mutual positive relationship with an external social worker. 
The respondents in our study $(\mathrm{N}=16)$ clearly stated that, from their point of view, the only possibility was to employ a school social worker by the school management. As they repeatedly stated, they did not trust the external institutions. In the respondents' statements we identified their fear and concerns related to revealing the system of functioning of the school to a foreign entity. At the same time, as the greatest advantage of this option they perceived the permanent presence of an expert at school and the opportunity to analyse the current situations and also the individual social risk factors together and on a daily basis and in the long run.

From our point of view, we can argue that whether a social worker is an employee of a school, a municipality, or another organisation, an important factor is that his professional recommendations are binding for the school and that he has space at school to effectively identify the necessary information and communicate with everyone in order to provide interventions and operate effectively from his position as soon as possible.

\section{Recommendations for practice}

Based on our study, we formulated individual recommendations for practice:

- We recommend further research on the possibilities of school social work in the Slovak conditions from different perspectives (from the perspective of social work professionals, from the perspective of experts working with children and youth, from the perspective of the pupil's family, from the perspective of pedagogical staff, children and youth, etc.)

- We recommend that the professional public should develop the systematic preparation of technical supporting documents necessary for the future implementation of school social work in Slovakia.

- We recommend making the effort to precisely and clearly define qualification requirements for the post of school social worker, his competences, activities, responsibilities, etc.

- We recommend enacting the obligation for each primary and secondary school to employ at least one professional employee.

- We recommend submitting suggestions and calls for funding schools from the state budget to cover costs for professional staff members.

- We recommend pointing out the importance of legislative changes and the legislative definition of a school social worker in the Act No. 245/2008 (School Law), the Act No. 317/2009 on pedagogical staff and professional staff, and in the Decree No. 437/2009 which defines the qualification assumptions and specific qualification requirements for individual categories of pedagogical staff and professional staff.

- We point out the need to develop a system of further education for school social workers - e.g. in some US states, in addition to the master's degree in social work, they have to obtain a certificate in the specialty in school social work.

- We recommend that social workers and the professional public promote and conduct education in the school environment, and inform the school management, pedagogical staff, children and youth and their families about the activities of school social workers in order to increase the number of professional staff in schools (at least, point out the possibility of employing a social worker at the post of social pedagogue, and the possibility of conducting educational counselling and prevention coordination by a professional staff member at school).

\section{Conclusion}

The history of school social work in the USA is more than a hundred years long. According to the International Organisation for School Social Work, Slovakia is among the more than 53 countries where school social work is carried out. However, this information does not reflect the reality (Klein, Rosinský, 2013). At present, this position has not been legislatively anchored yet; there is no funding available; the pedagogical public has not been informed about this possibility. This area has not been sufficiently explored; a professional debate that would have real impacts and power to influence its implementation in the Slovak educational system has only started. Several authors recommend opening a debate among professional staff, in particular a debate with social and special pedagogues to define the activities of these professionals and school social workers, and to reduce the extent of an overlap in the activities of individual professionals (Klein, Rosinský, 2013), and a debate within our profession among social 
workers, since as reported by several authors, the need to implement the post of social worker in the school environment corresponds with the growing tendency of the incidence of social risk factors in schools which are an important cause of school failure (Matulayová, 2013). In our opinion, it is important to encourage this debate also directly in schools, even though often there are no professional staff; the teachers are those who need to learn about the possibility, and that social workers may bring not only relief but also benefits to them. That's why we focused our study on school managers.

Raising awareness in schools is necessary; it is not possible to implement school social work in Slovakia if teachers and school managers do not want it. The head teacher is the only person who can employ a social worker as a school employee or allow a social worker to operate at a school as an employee of an external institution. The head teacher is an initiator and organizer of trends in his school and the atmosphere not only among the teachers. If the head teachers believe in the necessity and usefulness of school social work, then we can talk about a real perspective of social work in the school environment.

\section{Acknowledgements}

The paper is part of the UGA project "Possibilities of School Social Work in Slovakia" with the registration number IX/9/2018.

\section{References}

Act No. 245/2008 Coll. (2008) Zákon o výchove a vzdelávaní (školský zákon) a o zmene a doplnení niektorých zákonov [School Law]. Retrieved from https://www.slov-lex.sk/pravne-predpisy/SK/ZZ/2008/245/20190901

CSPP. (2018). Centrum špeciálno-pedagogického poradenstva. [Specialised pedagogic counselling centres]. Retrieved from http://poradnasnv.edupage.info/text2/?

Klein, V., Rosinský, R. (2013). Sociálna pedagogika pre pomáhajúce profesie.[Social pedagogy for helping professions]. Nitra: Univerzita Konštantína Filozofa v Nitre. ISBN 978-80-8094-835-1. 272.

Labáth, V. (1999). Školská sociálna práca - potreba alebo rozmar? [School Social Work - Need or Whim?]. In: Efeta. ISSN 1335-1397. IX(3), 2-3.

Lengyel, P. (2016). Školská sociálna práca. [School social work]. Retrieved from https://edusmile.sk/wpcontent/uploads/2016/08/\%C5\%A0kolsk\%C3\%A1-soc.pr\%C3\%A1ca.pdf

Link, R. (1991). Social work services to schools in the Midwestern United States and in London: A comparative study on the nature of guest status. In Social Work in Education. 13(5), 278-294.

Matulayová, T. (2013). Subjekty konstruují objekty. [Subjects construct objects]. In Sociální práce/Sociálna práca ISSN 1213-6204, 13(2), 14-16.

Moliková, Š. (2013). Anketa. [Survey] In Sociální práce/Sociálna práca. ISSN 1213-6204. 13(2), 11.

SSaSZ. (2018). Siet' škôl a školských zariadení SR. [Network of Schools and School Facilities of the SR]. Retrieved from https://www.minedu.sk/siet-skol-a-skolskych-zariadeni-slovenskej-republiky/.

Skyba, M. (2015). Školská sociálna práca. [School social work]. Prešov : Prešovská univerzita v Prešove. ISBN 978-80-5551287-7. 214.

SSWAA. (2018). Retrieved from https://www.sswaa.org/

Vasil’ová, V., Lovašová, S. (2018). Historická analýza vývoja sociálnej práce v školskom prostredí. In Fórum sociální práce. [Historical analysis of development of social work in school environment. In Social Work Forum]. 2018(1), $104-110$. Retrieved from https://dspace.cuni.cz/bitstream/handle/20.500.11956/100483/Veronika_Vasilova-Sona_Lovasova_104110.pdf? sequence $=1$ \&isAllowed $=y$

VUDPaP. (2018). Výskumný ústav detskej psychológie a patopsychológie. [Research Institute of Child Psychology and Pathopsychology]. Retrieved from http://www.vudpap.sk/adresar-cpppap/.

Zeitlin, A. et al. (2005). Helping social workers address the educational needs of foster children. In Child abuse \& neglect ISSN 01452134. 29(7), 811-823. 